\title{
Physiological and Psychological Effects of Vibroacoustic Stimulation to Scapular and Sacrum of Supine Position
}

\author{
Seung Yeop Lim ${ }^{1}$, Hyun $\mathrm{Heo}^{2}$, Sang Ho Kim ${ }^{2}$, Byeong Hee Won ${ }^{1}$ \\ ${ }^{1}$ Smart Welfare Technology R\&D Group, Korea Institute of Industrial Technology, Cheonan, 331-822 \\ ${ }^{2}$ Solco Biomedical Institute, Pyeongtaek, 451-852
}

\begin{abstract}
Objective: This research measured physiological and psychological effects of Vibroacoustic stimulation(VA) to scapular and sacrum of supine position on the mattress. Background: When vibroacoustic stimulation applies to human body, it has a positive influence on physiological and psychological effects by stimulating the organs, tissues and cells of whole body. Method: This experiment was conducted to 10 normal males in two conditions: no stimulation and vibroacoustic stimulation. No stimulation experiment was executed as a supine position for 30 minutes without any vibrational stimulus, while vibroacoustic stimulation was transmitted by the vibrational speaker, which uses $40 \mathrm{~Hz}$ frequency. Subjects had a laser Doppler flowmeter probe in scapular, sacrum, and also had 8 channel electroencephalogram(EEG) measurement sensor in the scalp. Blood pressure and skin temperature were measured in two conditions with an underlying posture for 30 minutes. Additionally, blood flow rate and EEG were measured before and after for two minutes on two conditions. Results: According to the vibroacoustic stimulation, blood flow rate and skin temperature were increased, while blood pressure was decreased. When using vibroacoustic stimulation compared to no stimulation, blood flow rate went approximately two times higher, and skin temperature also higher 3 4 times. Furthermore, the relative alpha power of brain wave was significantly increased when we applied to vibroacoustic stimulation. Conclusion: This experiment tested the VAT embedded in mattress in two conditions. According to this experiment, VAT decreases blood pressure, improves not only a physiological effect on blood flow rate as well as skin temperature, but also psychological functions by increasing relative alpha power. Application: The results of the publishing trend analysis might help physiological and psychological effects of vibroacoustic stimulation.
\end{abstract}

Keywords: Vibroacoustic stimulation, Blood pressure, Blood flow rate, Skin temperature, Electroencephalogram

\section{Introduction}

진동(vibration)은 인체에 해로운 영향을 끼치는 자극으 로 간주되어 이를 줄이기 위한 기술개발이 발전되어 왔으나, 최근 진동자극의 주파수와 진폭을 조절하여 인체에 적용할 경우 긍정적인 효과가 나타난다는 연구결과들이 보고되고
있다. 진동자극에 대한 연구 분야는 전신진동자극(WBV, whole body vibration) 과 미세진동자극(VA, vibroacoustic stimulation)으로 나눌 수 있다. 전신진동자극은 진동판 (vibration plate) 위에 두 발로 선 자세에서 모터에 의한 기 계적 진동을 받는 것으로 근신경계의 기능 향상에 효과적인 자극 방법이다(Cardinals, 2003). 주로 운동선수들의 경기 력 향상을 위해 근력, 민첩성 등의 증진을 목적으로 적용된

Corresponding Author: Byeong Hee Won. Smart Welfare Technology R\&D Group, Korea Institute of Industrial Technology, Cheonan, 331-822. Mobile: +82-10-3731-8090, E-mail: bhwon@kitech.re.kr Copyright@2013 by Ergonomics Society of Korea(pISSN:1229-1684 eISSN:2093-8462). All right reserved.

(c) This is an open-access article distributed under the terms of the Creative Commons Attribution Non-Commercial License(http://creativecommons.org/licenses/by-nc/3.0/), which permits unrestricted non-commercial use, distribution, and reproduction in any medium, provided the original work is properly cited. http://www.esk.or.kr 
다. 미세진동자극은 사운드 스피커를 통한 치료 방법으로 $30 \sim 120 \mathrm{~Hz}$ 의 주파수를 이용하여 적용하며 전신의 기관, 조 직 및 세포를 자극하는 효과적인 방법이다. 주로 누운 자세 에서 적용하며 생리적 기능 향상 외에 심리적 안정감을 주 기 위해 적용된다(Wigram, 1996).

미세진동자극의 효과에 대해서 근 · 골격계, 혈관계, 통증 및 심리 등 다양한 분야의 연구가 보고되고 있다. Wigram과 Weekes (1989)는 뇌성마비 (cerebral palsy) 환자를 대 상으로 미세진동자극을 적용하였을 때, 근육 긴장 (muscle tone)을 감소시키는 효과를 보였으며, 관절의 구축으로 기형 이 발생한 환자에게 안전하며 효과적인 치료 방법으로 유효 성을 입증하였다. Burke와 Thomas (1997)는 무릎전치환술 (TKR, total knee replacement) 을 받은 고령자를 대상으로 미세진동자극을 적용하였을 때 관절가동범위(ROM, range of motion)가 증가하는 연구결과를 보고하였다. Wigram (1993)은 미세진동자극이 혈관을 넓혀 혈압을 낮춰주고, 혈액순환에 효과적이라는 연구결과를 보고하였다. Chesky (1992), Skille과 Wigram(1989)은 다발성 관절염, 류머 티즘 및 복통과 같은 통증 완화에 효과가 있다고 하였고, Chesky와 Michel(1997)은 수술 전 진정 (sedative)작용, 수술 후 통증 감소 및 입원 일수를 줄이는 효과가 있다고 보 고하였다. 이상의 연구들을 종합해보면 미세진동자극은 근 골격계 및 혈관계의 생리적인 기능 향상뿐 아니라 통증 감소 및 심리적 이완 상태에도 긍정적인 효과를 제공하는 것을 알 수 있다.

그러나, 선행연구의 대상자가 뇌성마비와 같은 신경계 질 환을 가진 피실험자로 되어 있어 질환의 반응 특성이 결과 에 영향을 끼칠 소지가 있다. 또한, 실험장비는 18 인치 사 운드 스피커를 매트리스의 상부와 하부에 각각 1 개씩 매립 한 실험장비를 사용하여 미세진동에 따른 측정 부위의 생리 적 특성을 보다 구체적으로 설명하는데 한계점을 가지고 있 었다.

국내의 경우, 사운드 스피커를 통한 미세진동자극이 인체 에 미치는 특성에 대한 연구가 일부 연구자들에 의해 수행되 고 있으나, 초기 단계에 있어 그 수가 많지 않은 편이다. 특 히 음악치료 (sound therapy) 와 혼용되어 사용되는 경우가 있어 연구주제가 뇌파분석을 통한 스트레스 및 우울증과 같 은 특정 분야에 치우쳐 있다. 또한, 미세진동자극의 일반적 인 측정 자세는 바르게 누운 자세인데, 이 자세에서 견갑골 (scapular)과 천골(sacrum) 부위는 접촉압력이 증대되어 조직의 혈류장애 등 생리적 문제가 발생할 수 있는 위험 부 위이다.

따라서, 본 연구에서는 정상 성인을 대상으로 누운 자세에 서 욕창 호발 부위인 견갑골과 천골 부위에 무자극 $\left(\mathrm{T}_{1}, \mathrm{no}\right.$ stimulation)과 미세진동자극 $\left(\mathrm{T}_{2}\right.$, vibroacoustic stimu- lation)을 주었을 때 생리적(혈압, 혈류량, 피부온도) 영향과 심리적(뇌파) 영향에 대해 규명하여 미세진동자극이 인체에 미치는 영향을 분석하고자 한다.

\section{Method}

\subsection{Subjects}

미세진동자극이 인체에 미치는 생리적 · 심리적 특성을 평 가하기 위해 한국인 표준체형 데이터 SIZEKOREA의 20 30 대 평균체형을 고려하여 신체 건강한 성인 남성 10 명을 대상으로 실험을 진행하였다. 실험에 앞서 유의사항을 숙지 시키고 병력과 생활습관에 대한 조사와 함께 신장, 체중 및 $\mathrm{BMI}$ (body mass index) 등 기본적인 신체 특성을 측정하 였다(Table 1).

Table 1. Basic information of subjects (M \pm SD)

\begin{tabular}{c|c|c|c}
\hline Age(years) & Weight $(\mathrm{kg})$ & Height $(\mathrm{cm})$ & BMI $\left(\mathrm{kg} / \mathrm{m}^{2}\right)$ \\
\hline $23.30 \pm 5.38$ & $68.74 \pm 8.20$ & $175.70 \pm 3.71$ & $22.25 \pm 2.46$ \\
\hline
\end{tabular}

\subsection{Experiment device}

\subsubsection{Vibroacoustic mattress}

실험에 사용한 매트리스는 미세진동자극이 가능한 S사의 제품으로써, 사이즈는 가로 $1,000 \mathrm{~mm}$, 세로 $2,000 \mathrm{~mm}$, 높 이 $80 \mathrm{~mm}$ 이다. 구조는 2중 구조(double-layer)의 형태로 상층부(upper part)과 하층부(lower part)로 구성되었다. 상층부는 PTC(positive-temperature coefficient) 소재의 면상발열체, 폴리에틸렌 폼(PE, polyethylene foam) 및 메 모리 폼(memory foam)으로 구성되어 있고, 하층부에는 메 모리 폼과 코코아 팜 및 견면으로 구성되었다.

미세진동자극이 인체에 미치는 특성을 알아보기 위해 주 요 압박 부위인 견갑골과 천골 부위에 진동 스피커를 배치 하였다. 진동 스피커는 피실험자의 신장에 따라 맞춤형으로 대응할 수 있도록 벨크로(velcro) 작업을 하여 상층부와 하 층부 사이에 위치시켰다(Figure 1).

\subsubsection{Measurement equipment}

미세진동자극에 대한 생리적 특성을 알아보기 위해 혈압, 혈류량 및 피부온도를 측정하였고, 심리적 특성을 알아보기 위해 EEG (electroencephalogram, WEEG-32, Korea)를 사용하여 뇌파를 측정하였다. 


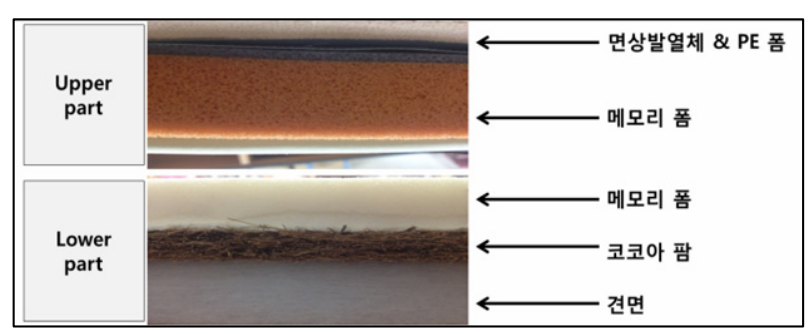

(a)

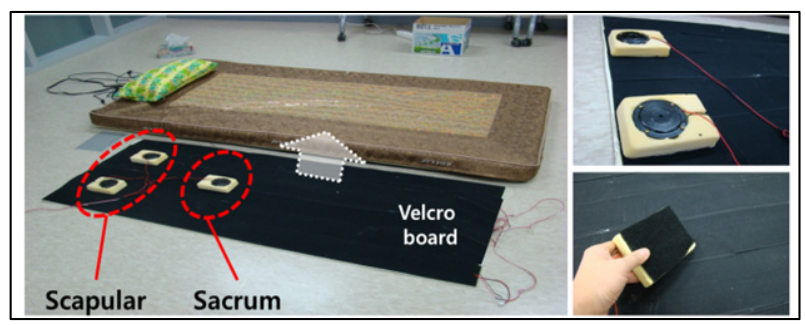

(b)

Figure 1. Experiment mattress (a) upper and lower part structure of the mattress (b) layout of vibration speaker

혈압은 전자혈압계 (automatic blood pressure monitor; easy-x800r, Korea)를 사용하여 측정하였다. 피실험자는 상의를 탈의하고 의자에 앉은 상태에서 5 10분간 안정을 취한 뒤 오른쪽 상완을 혈압계 커프에 깊숙이 넣고 측정하 였다.

혈류량은 레이저 도플러 혈류계(LDF, laser doppler flowmetry; moorVMS-LDF, United Kingdom)를 사용하 여 측정하였다. $2 \mathrm{ch}$ 의 실리콘 프루브(probe)를 주요 압박 부위 중 가장 골 돌출이 심한 부위를 촉지하여 견갑골의 견 갑극(scapular spine) 과 천골의 정중천골능 (median sacral crest) 부위에 의료용 종이반창고(micropore ${ }^{\mathrm{TM}}, 3 \mathrm{M}$, USA) 를 사용하여 부착하였다.

피부온도는 적외선 체열 측정기 (infrared thermograph imaging system; IRIS-XP, Korea)를 사용하여 측정하였 다. 적외선 체열 측정기는 피부표면에서 방출되는 극소량의 적외선을 감지하여 피부온도를 이미지화하여 표현한다. 측정 시 피실험자는 피험복을 모두 탈의하고 견갑골과 천골 부위 를 촬영하였다(Figure 2).

뇌파측정은 머리표면 총 8부위에서 단극유도(monopolar derivation) 방식으로 뇌파를 측정하였으며, $10 / 20$ 국제 전극 배치법(international 10/20 system)에 의해 차례로 전두엽 $(\mathrm{Fp} 1, \mathrm{Fp} 2)$, 두정엽 $(\mathrm{F} 3, \mathrm{~F} 4)$, 측두엽 (T3, T4), 후 두엽 $(\mathrm{P} 3, \mathrm{P} 4)$ 의 순서로 측정 전극을 부착하였다. 기준 전 극(reference electrode)은 오른쪽 귓볼 뒤, 접지 전극

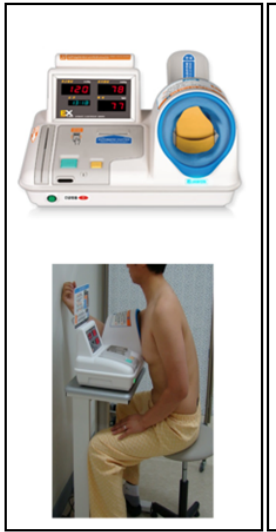

(a)

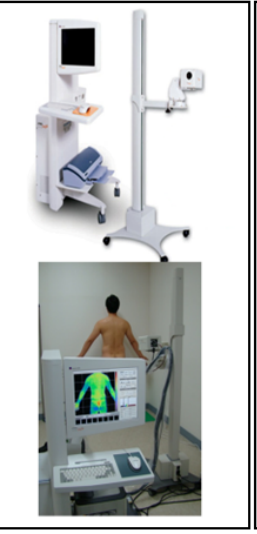

(b)

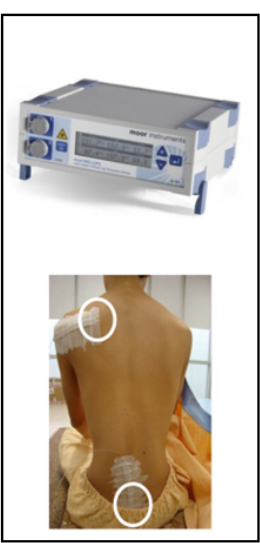

(c)
Figure 2. Physiological experiment system setup (a) automatic blood pressure monitor (b) infrared thermography imaging system (c) laser Doppler flowmetry

(ground electrode)은 왼쪽 귓볼 뒤에 부착하였다. 사용된 전극은 금으로 도포된 접시형태의 디스크 전극이며, 피부와 의 접촉저항을 최소화하기 위해 먼저 알코올 솜을 이용하여 머리표면의 이물질을 닦아낸 후, 접시 전극에 뇌파 전용 전 극 풀(elefix z-401ce, Nihon Kohden)을 묻혀 부착하였 다. 부착된 접시 전극 위에 거즈를 덮어줌으로써 머리표면에 잘 고정되도록 처치하였다(Figure 3).

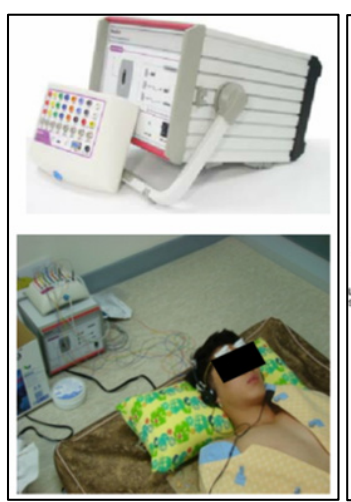

(a)

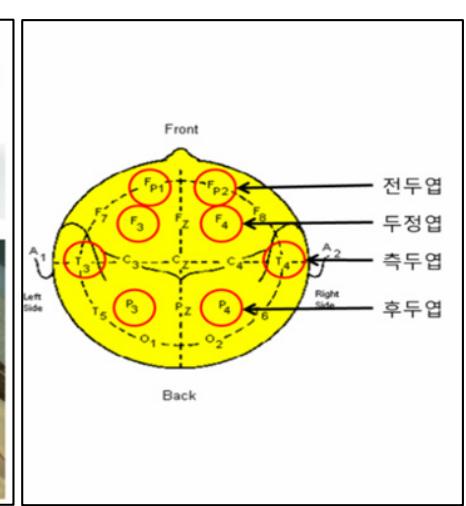

(b) (a) electroencephalogram (b) $8 \mathrm{ch}$ of international 10/20 system

Figure 3. Psychological experiment system setup

\subsection{Experiment design}

실험실은 피실험자의 피부온도에 영향을 주지 않는 공기 
조절이 가능한 방으로 구성하였고, 실내온도 $23 \sim 25^{\circ} \mathrm{C}$, 습 도 30 75\% 내외로 유지시켰다.

피실험자의 기본정보 수집을 위해 체성분 분석기(inbody 520, biospace, Korea)를 사용하여 신장, 체중, 체질량지수 (BMI)를 측정하였다. 피험복으로 갈아입고 실험실에서 45 50 분간 대기하면서 실험실 환경에 적응하도록 하였다. 피험 복을 탈의한 뒤 5 10분 동안 추가로 대기하면서 실내온도 에 적응시킨 후, 사전측정으로 혈압과 견갑골 및 천골 부위 의 피부온도를 측정하였다. 미세진동자극이 주어지는 부위의 혈류량 측정을 위해 레이저 도플러 혈류계의 실리콘 프루브 를 견갑골과 천골 부위에 각각 부착하였고, 뇌파측정을 위해 $\mathrm{EEG}$ 전극 8채널과 기준 및 접지 전극을 의료용 풀을 사용 하여 두피에 부착하였다. 피실험자를 실험용 매트리스 위에 바르게 눕히고, 견갑골과 천골 부위에 미세진동자극이 올 수 있도록 진동 스피커를 배치하였다. 모든 실험준비가 끝난 뒤 두 눈을 감은 상태에서 사전 뇌파와 혈류량을 각각 2 분간 측정하고, 30 분 동안 자극을 준 뒤 사전측정과 동일하게 사 후측정을 실시하였다.

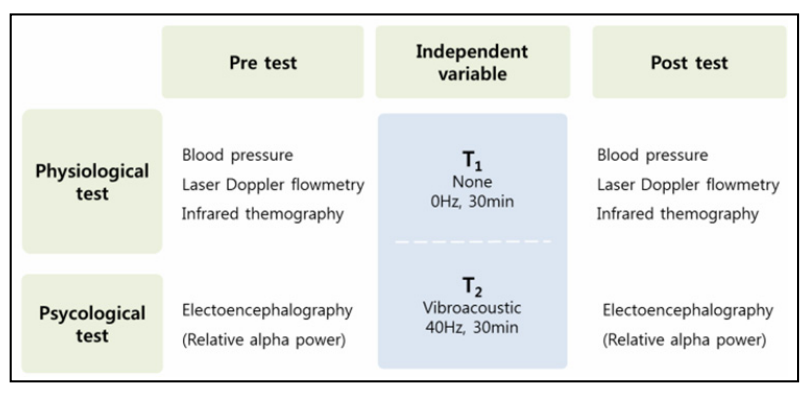

(a)

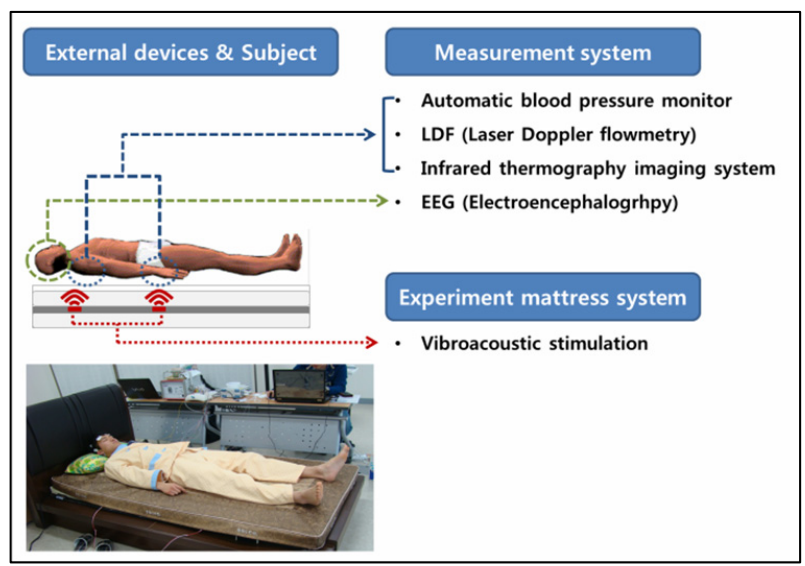

(b)

Figure 4. (a) Experimental protocol (b) Configuration of experiment
무자극 조건 $\left(\mathrm{T}_{1}, \mathrm{OHz}\right)$ 은 진동자극 없이 30 분간 누운 상 태를 유지하는 것이며, 미세진동자극 조건 $\left(\mathrm{T}_{2}, 40 \mathrm{~Hz}\right)$ 은 미 세진동자극을 30 분간 견갑골과 천골 부위에 적용하는 것으 로 정하였다(Figure 4).

Rittweger (2003)은 $20 \mathrm{~Hz}$ 이하의 진동은 근육의 이완을 유발하며 $50 \mathrm{~Hz}$ 를 초과하는 진동은 근육통이나 혈종을 유발 할 수 있으므로 20 50Hz사이의 진동이 인체에 안전한 범 위로 보고하였다. 이에 본 연구에서는 $40 \mathrm{~Hz}$ 의 주파수를 선 택하여 실험하였다.

$\mathrm{T}_{1}$ 과 $\mathrm{T}_{2}$ 의 실험 순서는 무작위 순서로 정하였으며, 각 실 험 조건간 영향이 다음 실험에 미치지 않기 위해 하루에 1 가 지 조건만 실험하여 총 2 일 동안 수행하였으며, 피실험자는 실험 기간 동안 동일한 시간에 참석하였다.

\subsection{Data analysis}

혈압은 각 조건 별 자극 전 · 후의 최고혈압과 최저혈압을 기록하여 변화를 분석하였다.

혈류량은 혈류량 분석 소프트웨어(moor instrument, moorVMS-PC V3.1 for vascular monitor system)에서 분석하였고, 데이터의 분석 과정은 측정된 데이터의 자극 전 · 후 각각 2 분간 측정 구간을 관심영역 $(\mathrm{ROI}$, region of interest)으로 설정하고 평균, 표준편차 값을 구하였다.

피부온도는 적외선 체열 측정 · 분석 소프트웨어(IRIS-XP $\mathrm{SCAN})$ 에서 분석하였고, 데이터의 분석 과정은 측정된 결과 화면에 주요 압박 부위를 관심영역으로 설정하고 설정된 부 위의 평균, 표준편차 값을 구하였다.

뇌파는 $8 \mathrm{ch}$ 로부터 받은 피실험자의 뇌파신호를 전용분석 소프트웨어인 telescan 3.03ver을 이용하여 데이터를 측정 하였다. 측정된 데이터는 $256 \mathrm{~Hz}$ 샘플링 주파수, $0.5 \sim 50 \mathrm{~Hz}$ 의 대역 필터(band pass), $16 \mathrm{bit} \mathrm{AD}$ 변환에 의해 컴퓨터에 저장되었다. 뇌파는 델타 $(\delta, 0 \sim 4 \mathrm{~Hz})$, 쎄타 $(\theta, 4 \sim 8 \mathrm{~Hz})$, 알 파 $(\alpha, 8 \sim 13 \mathrm{~Hz})$, 베타 $(\beta, 13 \sim 30 \mathrm{~Hz})$, 감마 $(\gamma, 30 \sim 50 \mathrm{~Hz})$ 의 5 개의 파형이 나온다. 이중 알파파는 깨어 있으면서 편안 한 상태일 때 많이 활성화되는 특징이 있어 이를 참고하여 전체 뇌파 중 알파파가 차지하는 비율인 상대알파파워를 구 하였다. 상대알파파워를 계산할 때, 안구의 움직임에 대한 델타파의 오염을 피하기 힘드므로 델타파의 영역을 제외한 전체파워에 대한 알파파워의 비율을 보는 것이 일반적으로 사용되고 있다.

$\alpha$-wave power

(8 13Hz)

Relative $\alpha$-wave power $=\frac{}{\text { theta }(\theta)+\text { alpha }(\alpha)+\operatorname{beta}(\beta)+\operatorname{gamma}(\gamma) \text { power }}$ (4 50Hz) 
Table 2. Result data of physiological and psychological effects

\begin{tabular}{|c|c|c|c|c|c|c|c|}
\hline & & \multicolumn{3}{|c|}{ No stimulation $\left(\mathrm{T}_{1}\right)$} & \multicolumn{3}{|c|}{ Vibroacoustic stimulation $\left(\mathrm{T}_{2}\right)$} \\
\hline & & Pre & Post & $P$-value & Pre & Post & $P$-value \\
\hline \multirow{2}{*}{$\begin{array}{l}\text { Blood pressure } \\
\quad(\mathrm{mmHg})\end{array}$} & $\operatorname{Max}$ & $114.1 \pm 11.2$ & $121.4 \pm 13.0$ & $0.005^{*}$ & $123.1 \pm 9.7$ & $113.8 \pm 13.1$ & $0.035^{*}$ \\
\hline & Min & $69.9 \pm 7.0$ & $72.4 \pm 6.2$ & 0.288 & $75.5 \pm 12.2$ & $69.2 \pm 7.8$ & 0.286 \\
\hline \multirow{2}{*}{$\begin{array}{l}\text { Blood flow rate } \\
\text { (PU) }\end{array}$} & Scapular & $8.1 \pm 5.0$ & $11.8 \pm 4.9$ & $0.005^{*}$ & $9.8 \pm 5.4$ & $18.0 \pm 16.0$ & $0.027^{*}$ \\
\hline & Sacrum & $11.5 \pm 3.5$ & $14.3 \pm 4.4$ & $0.001^{*}$ & $10.8 \pm 3.1$ & $15.2 \pm 2.8$ & $0.000^{*}$ \\
\hline \multirow{2}{*}{$\begin{array}{l}\text { Body temperature } \\
\left({ }^{\circ} \mathrm{C}\right)\end{array}$} & Scapular & $31.3 \pm 0.6$ & $31.9 \pm 0.6$ & $0.003^{*}$ & $31.0 \pm 0.8$ & $33.0 \pm 1.1$ & $0.001^{*}$ \\
\hline & Sacrum & $31.4 \pm 1.2$ & $31.9 \pm 0.9$ & $0.034^{*}$ & $31.1 \pm 1.5$ & $33.1 \pm 0.8$ & $0.010^{*}$ \\
\hline \multirow{8}{*}{$\begin{array}{l}\text { Relative } \\
\alpha \text {-power }\end{array}$} & $1 \mathrm{ch}$ & $0.414 \pm 0.148$ & $0.363 \pm 0.125$ & 0.174 & $0.260 \pm 0.109$ & $0.404 \pm 0.135$ & $0.007^{*}$ \\
\hline & $2 \mathrm{ch}$ & $0.424 \pm 0.164$ & $0.390 \pm 0.132$ & 0.323 & $0.282 \pm 0.116$ & $0.405 \pm 0.148$ & $0.016^{*}$ \\
\hline & $3 \mathrm{ch}$ & $0.467 \pm 0.179$ & $0.438 \pm 0.173$ & 0.443 & $0.306 \pm 0.104$ & $0.455 \pm 0.156$ & $0.002^{*}$ \\
\hline & $4 \mathrm{ch}$ & $0.466 \pm 0.196$ & $0.438 \pm 0.180$ & 0.399 & $0.324 \pm 0.102$ & $0.439 \pm 0.146$ & $0.003^{*}$ \\
\hline & $5 \mathrm{ch}$ & $0.397 \pm 0.166$ & $0.380 \pm 0.163$ & 0.399 & $0.251 \pm 0.065$ & $0.353 \pm 0.123$ & $0.005^{*}$ \\
\hline & $6 \mathrm{ch}$ & $0.444 \pm 0.185$ & $0.407 \pm 0.192$ & $0.040^{*}$ & $0.267 \pm 0.064$ & $0.342 \pm 0.112$ & $0.043^{*}$ \\
\hline & $7 \mathrm{ch}$ & $0.589 \pm 0.194$ & $0.583 \pm 0.171$ & 0.756 & $0.467 \pm 0.153$ & $0.557 \pm 0.155$ & $0.025^{*}$ \\
\hline & $8 \mathrm{ch}$ & $0.578 \pm 0.231$ & $0.572 \pm 0.165$ & 0.891 & $0.483 \pm 0.126$ & $0.590 \pm 0.143$ & $0.045^{*}$ \\
\hline
\end{tabular}

$(* p<0.05)$

측정된 데이터에 대한 통계분석은 각 조건 별 사전, 사후 값과 자극 조건간 생리적, 심리적 특성에 미치는 영향에 대 하여 분석하기 위해 대응표본 $\mathrm{t}$-검정 (paired $t$-test)으로 분석하였다. 본 연구의 통계학적 유의성을 검정하기 위한 유의수준은 $p<0.05$ 로 하였고, 통계처리를 위해 윈도우용 SPSS 12.0 을 사용하였다.

\section{Results \& Discussion}

진동 스피커가 매립된 매트리스에 누운 상태에서 견갑골 과 천골 부위에 미세진동자극이 미치는 생리적, 심리적 영향 에 대한 결과 값을 Table 2 에 정리하였다. 그 결과를 이용하 여 조건에 따른 사전, 사후의 차이 값을 Figure 5, 6에 기록 하였다.

\subsection{No stimulation case $\left(T_{1}\right)$}

\subsubsection{Physiological effect}

실험결과 혈압, 혈류량, 피부온도 모두 사전에 비해 사후 의 값이 증가하였다.

최고혈압은 유의한 차이를 보이며 사전에 비해 사후 값이 $7.3 \mathrm{mmHg}(6.4 \%)$ 상승하였고, 최저혈압은 유의한 차이를
보이지 않았지만 사전에 비해 $2.5 \mathrm{mmHg}(3.6 \%)$ 상승하였다. 혈류량은 측정 부위 모두에서 유의한 차이를 보이며 증가하 였다. 견갑골 부위에서 사전에 비해 3.7PU(45.6\%) 증가하 였고, 천골 부위에서는 $2.8 \mathrm{PU}(24.0 \%)$ 증가하였다. 피부온 도는 측정 부위 모두에서 유의한 차이를 보이며 증가하였다. 견갑골 부위에서 $0.6^{\circ} \mathrm{C}(2.1 \%)$ 증가하였고, 천골 부위에서는 $0.5^{\circ} \mathrm{C}(1.7 \%)$ 증가하였다(Figure 5).

무자극은 30 분간 자극 없이 누운 자세를 유지하는 것으로 신체활동이 없는 상태이다. 피부온도는 환경온도에 영향을 받으며 항상성을 유지하는데, 신체활동이 없는 경우엔 외부 로 열 손실을 막기 위해 혈관이 수축하고 혈류량을 감소시키 는 생리적인 현상이 발생한다. 본 실험에서 무자극일 때 혈 압이 증가한 것도 체내 열 손실을 막기 위한 생리적 기전으 로 판단된다.

그러나, 혈류량과 피부온도는 사전에 비해 사후에 상승하 였는데, 혈류량에 영향을 주는 물리적 압박 때문으로 판단된 다. Won(2011)에 따르면, 외부에서 작용하는 부하에 의해 조직이 압박을 받게 되면 허혈에 의한 대사장애가 생기고 이 러한 불평형 상태를 해소하기 위해 조직의 자율조절 (auto regulation) 기능에 의한 반응충혈(reactive hyperemia) 현 상이 발생한다고 하였다. 이러한 반응충혈은 국부적인 허혈 (ischemia)에 의해 조직의 대사장애(metabolic disorder)가 발생했을 때 자율적으로 균형을 회복시키기 위한 생리적인 현상이며, 반응충혈 상태가 되면 정상보다 더 많은 혈류를 


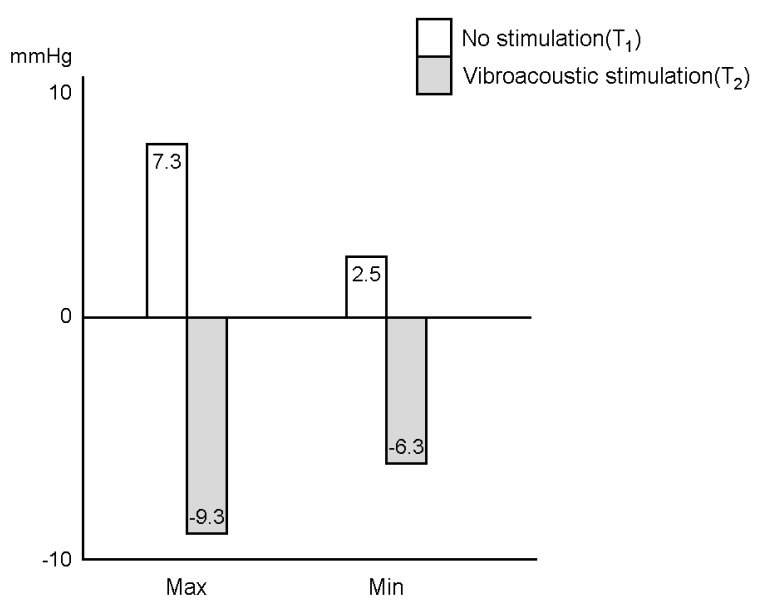

(a)

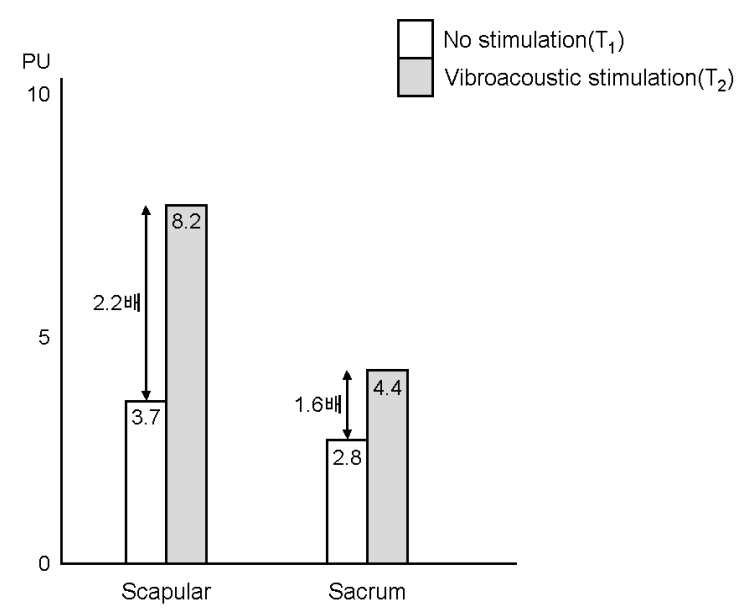

(b)

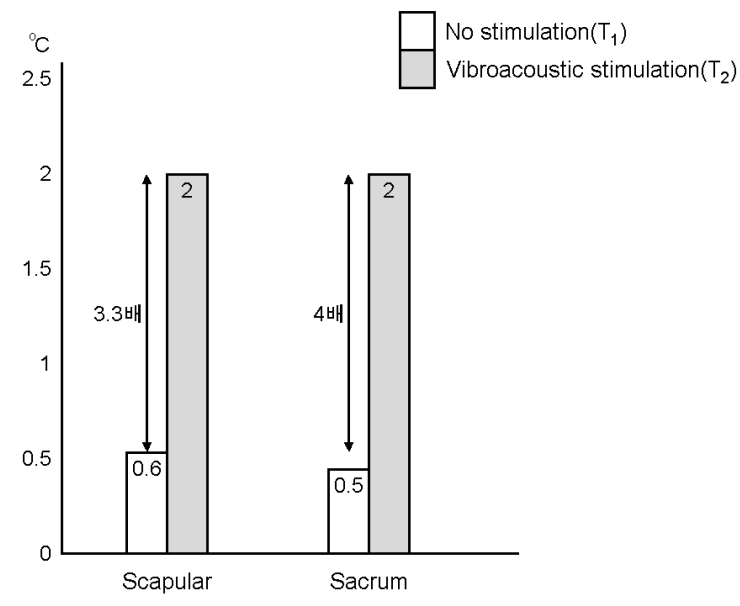

(c)

Figure 5. Physiological effects of difference value between the pre-test and post-test (a) blood pressure (b) blood flow rate (c) skin temperature
공급하는 것으로 알려져 있다. 본 연구에서 30 분간 누운 자 세가 측정 부위의 압박을 유발시켰고, 그로 인해 견갑골과 천골 부위에 반응충혈 현상을 일으켜 혈류량과 피부온도가 증가한 것으로 판단된다.

또한, 누워있는 자세로 인해 관심 부위의 혈류량과 피부온 도가 상승한 것으로 판단된다. 실험 자세인 30 분간 누워있 는 자세는 관심영역부위가 외부 환경에 노출되지 않으며 매 트리스와 접촉되는 자세이다. 이럴 경우 관심 부위는 외부와 의 열 교환이 발생하지 않게 되고 그로 인해 국소 부위의 체 온이 내려가지 않게 된다.

따라서, 무자극일 경우 체온이 증가한 것은 자극에 따른 내부온도의 상승이 아닌 물리적 압박으로 인한 반응충혈과 외부와의 열 교환 차단에 의한 영향으로 판단된다.

\subsubsection{Psychological effect}

실험결과 상대알파파워 값은 유의한 차이를 보이지 않았 으나 측정된 모든 채널에서 사전에 비해 사후에 감소하였다. 사전 상대알파파워와 비교하여 사후 상대알파파워의 감소는 사전측정 상태에 비해 심리적으로 이완되거나 안정되지 못 하고 있음을 나타낸다(Figure 6).

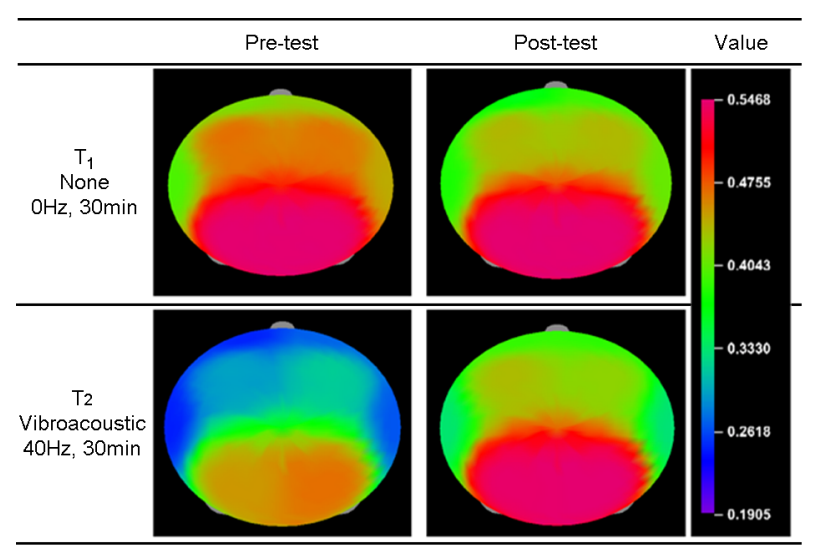

Figure 6. Brain map of relative $\alpha$-power

\subsection{Vibroacoustic stimulation case $\left(T_{2}\right)$}

\subsubsection{Physiological effect}

실험결과, 혈압은 사전에 비해 사후 값이 감소하였고, 혈 류량과 피부온도는 사전에 비해 사후 값이 증가하였다.

최고혈압은 유의한 차이를 보이며 사전에 비해 사후 값이 $9.3 \mathrm{mmHg}(7.6 \%)$ 감소하였고, 최저혈압은 유의한 차이를 보이지 않았지만 사전에 비해 $6.3 \mathrm{mmHg}(8.3 \%)$ 감소하였다. 혈류량은 측정 부위 모두에서 유의한 차이를 보이며 증가하 
였다. 견갑골 부위에서 사전에 비해 사후의 값이 $8.2 \mathrm{PU}$ $(83.6 \%)$ 증가하였고, 천골 부위에서는 $4.4 \mathrm{PU}(41.6 \%)$ 증 가하였다. 피부온도는 측정 부위 모두에서 유의한 차이를 보 이며 증가하였다. 견갑골 부위에서 $2.0^{\circ} \mathrm{C}(6.5 \%)$ 상승하였고, 천골 부위에서도 $2.0^{\circ} \mathrm{C}(6.6 \%)$ 상승하였다(Figure 5).

미세진동자극은 무자극에 비해 혈관확장의 효과, 혈류량 개선 및 피부온도의 증가가 2 배 이상 높게 측정되었다. 이는 미세진동자극이 생리적 특성에 효과적으로 작용하고 있음을 뜻한다. 피부온도는 혈류량에 영향을 받는다. 미세진동자극 에서 견갑골 부위의 혈류량은 천골 부위의 혈류량보다 약 2 배 가까운 증가율을 보였으나, 피부온도는 거의 유사한 증 가 값을 나타냈다. 이것은 혈류량이 아무리 높아져도 피부온 도는 일정온도 이상 올라가면 더 이상 올라가지 않고 유지된 다는 선행연구와 일치한다(Park, 2001).

\subsubsection{Psychological effect}

실험결과, 상대알파파워 값은 측정된 모든 채널에서 유 의한 차이를 보이며 증가하였다(Table 2). 특히 후두부 $(7,8 \mathrm{ch})$ 와 두정엽 $(3,4 \mathrm{ch})$ 부위에서 높게 측정되었는데, 이 부위는 알파파가 주로 활성화 되는 부위로 미세진동자극이 긴장 완화 및 이완에 긍정적인 반응을 한 것으로 판단된다.

생리적 특성 실험을 통해 미세진동자극이 혈관을 확장시 키는 것을 확인할 수 있었다. 일반적으로 혈관이 확장되어 혈류량이 증가되면 혈액 속에 있는 백혈구의 활동이 활발해 지고 그로 인해 면역력이 증가되면서 교감신경 기능이 억제 되어 통증 완화, 긴장 이완의 효과가 있다. 따라서, 미세진동 자극이 심리적으로 이완의 효과를 준 것으로 보이며, 그 결 과 상대알파파가 사전에 비해 더 높게 활성화 된 것으로 판 단된다.

\subsection{Comparison of no stimulation and vibroacoustic stimulation}

$\mathrm{T}_{1}$ 의 혈압은 증가하였으나 $\mathrm{T}_{2}$ 의 혈압은 감소한 것을 미 루어 보아 미세진동자극이 혈압을 감소시키는 역할을 하는 것으로 판단된다. Lee(2009)에 따르면 혈압은 여러 기능계 의 상호작용으로 조절되는데, 그 중 가장 신속하게 반응하는 기전은 자율신경계를 통한 신경반사이다. 자율신경계의 교감 신경은 긴장 상태를 유지하여 혈관을 수축시키고 혈압을 증 가시키는 역할을 하고, 부교감신경은 이완 상태를 유지하여 혈관을 확장시키고 혈압을 낮추는 특성을 보인다. 특히, 이 러한 혈관수축 효과는 피부에서 크게 나타난다.

본 연구에서 미세진동자극이 상대알파파워의 값을 향상시 켜 피실험자가 심리적으로 안정되는 것을 확인하였다. 이것 은 미세진동자극이 부교감신경의 활성도를 높여 혈관이 확
장되고 혈압이 감소된 것으로 판단된다.

혈류량과 피부온도의 경우에도 혈관의 수축, 이완에 영향 을 받으므로 $\mathrm{T}_{2}$ 가 $\mathrm{T}_{1}$ 에 비해 혈류량과 피부온도를 긍정적으 로 개선시키는데 기여한 것으로 판단된다.

\section{Conclusion}

본 연구에서는 진동 스피커가 내장된 매트리스에서 견갑 골과 천골 부위에 무자극과 미세진동자극을 주었을 때 인체 에 미치는 영향에 대한 실험을 수행하였다.

실험은 신체 건강한 성인 남성을 대상으로 실시하였으며, 각 자극에 따른 혈압, 혈류량, 피부온도를 통한 생리적인 영 향과 상대알파파워를 통한 심리적인 영향을 측정하여 분석하 였다.

실험결과, 미세진동자극을 주었을 때가 아무런 자극을 주 지 않았을 때보다 혈압이 감소하였고, 혈류량과 피부온도가 증가하였으며 상대알파파워 값도 유의하게 증가하였다.

Wigram(1996)은 미세진동자극이 혈관확장 및 혈액순환 을 개선시켜 준다고 하였다. 혈류량은 혈관의 수축. 이완에 영향을 받고, 피부온도는 혈류량에 영향을 받는다. 본 연구 에서 미세진동자극으로 사후 혈압이 감소하고 혈류량이 증 가한 것을 통해 혈관이 확장된 것을 알 수 있었고, 그로 인 해 피부온도가 상승한 것으로 판단된다. Hooper (2002)은 미세진동자극이 심리적 안정, 스트레스 감소와 같은 이완효 과가 있다고 하였다. 알파파는 깨어있는 상태에서 긴장 이완 상태나 심리적으로 안정 시 발생하는 것으로 본 연구에서 미 세진동자극으로 상대알파파워 값이 증가한 것을 통해 심리 적으로 이완되고 안정된 것을 알 수 있었다.

본 연구결과를 통해 미세진동자극이 가능한 매트리스는 장시간 와상 상태에 있는 고령자나 장애인을 대상으로 혈액 순환 장애 및 심리적 스트레스를 개선시키는 감성재활 보조 기구로 활용할 수 있을 것으로 보여진다.

그러나 본 연구는 $40 \mathrm{~Hz}$ 의 고정 주파수의 미세진동자극에 대해 국소 부위의 생리적 특성을 본 것으로, 국소 부위의 미 세진동자극이 신체 전반적인 특성이라고 보기엔 어려우며, 신체 건강한 성인 남성을 대상으로 실시하였기에 모든 일반 인의 특성이라고 하기엔 한계점이 있다.

추후 좀 더 많은 피실험자를 대상으로 미세진동자극이 인 체에 미치는 생리적 · 심리적 특성에 대하여 신체 전반적인 특성에 대한 연구를 실시할 경우 보다 양질의 연구가 될 수 있을 것이다. 


\section{Acknowledgements}

This study was supported by a grant of the Korea Healthcare R\&D Project, Ministry of Health \& Welfare, Republic of Korea (A120110).

\section{References}

Burke, M. and Thomas, K., "Use of physioacoustic therapy to reduce pain during physical therapy for total knee replacement patients over age 55". Music Vibration and Health, Cherry Hill, NJ: Jeffrey Books, 99-106, 1997

Cardinals, M. and Bosco, C., "The use of vibration as an exercise intervention". Exercise and sport sciences reviews, 31(1), 3-7, 2003.

Cass, H., Slonims, V., Weekes, L., Wigram, T. and Wisbeach, A., "Therapy services for Rett Syndrome: how well does provision match specific needs", Royal Society of Medicine, London, 1995.

Chesky, K.S. and Michel, D., "From passive to active patient involvement: The potential for music and music vibration in pre-emptive analgesia". Alternative Therapies in Clinical Practice, 4, 168-173, 1997.

Chesky, K.S., "The effects of music and music vibration using the MVT on the relief of rheumatoid arthritis pain", Dissertation Abstracts International, 53(8), 2725B, 1992.

Choi, D.H., "A study on the development of tissue blood flowmeter by laser Doppler flowmetry", Korea research institute of standards and science, 1993.

Hagisawa, S., Ferguson-Pell, M., Cardi, M. and Miller, D., "Assessment of skin blood content and oxygenation in spinal cord injured subjects during reactive hyperemia", Journal of rehabilitation research and development, 31(1), 1-14, 1994.

Hooper, J., "Is VA therapy, music therapy", Music Therapy Today, 29, 35, 2002.

Min, J.Y. and Bea, J.J., "Study on the effects of vibration exercise for the human body", The Korea Society of Mechanical Engineers, 2672-2677, 2009.

Rittweger, J., Mutschelknauss, M. and Felsenberg, D., "Acute changes in neuromuscular excitability after exhaustive whole body vibration exercise as compared to exhaustion by squatting exercise", Clinical Physiology and function imaging, 23(2), 81-86, 2003.

Size Korea Home Page, http://sizekorea.kats.go.kr (retrieved June 1, 2013). Skille, O., Wigram, T. and Weekes, L., "Vibroacoustic stimulation therapy: The effect of low frequency sound on specific physical disorders and disabilities". Journal of British Music Therapy, 3(2), 6-10, 1989.

The Korean society of hypertension. Textbook of Hypertension, medbook, 51-58, 2009.

The Korean society of thermology of Korea home page, http:// www.thermology.or.kr (retrieved June 1, 2013).
Thompson, D.A., "Critical review of the literature on pressure ulcer aetiology", Journal of Wound Care, 14(2), 87-90, 2005.

Uematsu, S., "Symmetry of skin temperature comparing one side of the body to the other", Thermology, 1(1), 4-7, 1985.

Vibroacoustic therapy of Canada home page, http:// www.vibroacoustictherapy.com (retrieved June 1, 2013).

Wigram, A. and Weekes, L., "A project evaluation the difference in therapeutic treatment between the use of low frequency sound and music, and music along, in reducing high muscle tone in multiply handicapped people, and edema in mentally handicapped people". Second ISVA Symposium in Steinke. 1989.

Wigram, A.L., "The feeling of sound - The effect of music and low frequency sound in reducing anxiety in challenging behavior in clients with learning difficulties", In Payne, H., "Handbook of inquiry in the arts therapies: One River, Many Currents", London: Jessica Kingsley Publishers, 1993.

Wigram, T., "The effects of vibroacoustic stimulation therapy on clinical and non-clinical population", London University, 1996.

Won, B.H., "Effects of alternating pressure profile load to dynamic tissue perfusion characteristics", Hanyang University, 2011.

\section{Author listings}

Seung Yeop Lim: sapns@kitech.re.kr

Highest degree: MS, Department of Ergonomic Therapy, Yonsei Univ. Position title: Researcher, Smart Welfare Technology R\&D Group,

KITECH

Areas of interest: Ergonomics, Physical Therapy

Hyun Heo: gigus1@nate.com

Highest degree: MS, Department of Biomedical Engineering, Yonsei Univ.

Position title: Team Manager, Solco Biomedical Institute, SOLCO

Biomedical Co., Ltd

Areas of interest: Biomedical Optics Engineering

Sang Ho Kim: shkim@solco.co.kr

Highest degree: Ph.D, Department of Biomedical Engineering, Catholic Univ.

Position title: Deputy Director, Solco Biomedical Institute, SOLCO

Biomedical Co., Ltd

Areas of interest: Biomedical Engineering 
Byeong Hee Won: bhwon@kitech.re.kr

Highest degree: Ph.D, Department of Precision Mechanical Engineering, Hanyang Univ.

Position title: Principal Researcher, Smart Welfare Technology R\&D

Group, KITECH

Areas of interest: Biomechanics, Gerontechnology
Date Received : 2013-07-03

Date Revised :2013-08-01

Date Accepted : 2013-08-01 